\title{
Effect of Afghan Talkhak (Acroptilon Repens) Aqueous Extract on Blood Glucose Level in Diabetic Rats
}

\author{
Research Article
}

\author{
Banafsha Zainal Bayat ${ }^{1}$, Kawsar Alami1, Sayed Yousof Mousavi ${ }^{*}$ \\ 1. Research and Technology Center, Khatam Al-Nabieen University, Kabul, Afghanistan. \\ 2. Assistant Professor, Department of physiology, \\ Khatam Al-Nabieen University, $1^{\text {st }}$ street of Karte 4, Kabul, Afghanistan.
}

\begin{abstract}
The aim of this study is the evaluation of the effect of Afghan talkhak (Acroptilon Repens) root aqueous extract on blood glucose level of diabetic rats. Rats were randomly divided into 5 groups (1 Normal, 1 Diabetic and 3 extract groups). Experimental diabetes was induced by single-dose intraperitoneal (i.p.) injection of streptozotocin $(55 \mathrm{mg} / \mathrm{kg})$ in diabetic and extracts groups. 72 hour later, the induction of diabetes was approved and extract groups were received Acroptilon Repens aqueous extract $(200,300,400 \mathrm{mg} / \mathrm{kg})$ by i.p. administration for 15 days. The blood glucose level and body weight of all groups were measured on baseline, $0,5,10$ and $15^{\text {th }}$ days. The glucose tolerance test had performed on days 0 and 15. The results showed that aqueous extract of Afghan Acroptilon Repens in extract groups (200 and $300 \mathrm{mg} / \mathrm{kg}$ ) could significantly decrease the blood glucose level, and improve the glucose tolerance, as compared with the diabetic group $(\mathrm{P}<0.0001)$. However, there was not a significant difference in the blood glucose level and glucose tolerance test among the group which received $400 \mathrm{mg} / \mathrm{kg}$ dose of Acroptilon Repens and the diabetic group ( $\mathrm{P}>0.05)$. In conclusion, Acroptilon Repens root aqueous extract possessed antihyperglycemic activity.
\end{abstract}

Key Words: Afghanistan, Acroptilon Repens, Blood glucose level, Diabetic rat.

\section{Introduction}

Diabetes mellitus is one of the major health problems in the world, which is associated with serious complications and mortality (1). High glucose level in the plasma due to defects in insulin secretion, action or both, is the major feature of diabetes (2). It can lead to various complications including organ damage, especially in the eye, kidney, nerve, heart and vasculatures (3). Most of these complications have resulted from chronic hyperglycemia (4). Therefore, the main purpose of diabetes treatment is the prevention of its complications through the control of hyperglycemia (4-6).

There are many drugs for reducing blood glucose level, such as sulfonylureas and biguanides, which play a major role in the control of hyperglycemia $(7,8)$. However, adverse side effects and toxicity of these synthetic drugs increases the tendency of using natural remedies in treatment of many disorders. Many natural products such as plants, fruits and nuts have potential pharmacological activities (8-13). Also, because of

\section{* Corresponding Author:}

Sayed Yousof Mousavi

Assistant Professor,

Department of Physiology,

Khatam Al-Nabieen University,

$1^{\text {st }}$ street of Karte 4, Kabul, Afghanistan.

Email Id: mousavi.knurtc@knu.edu.af economic problems and the lack of some synthetic drugs in developing countries, the usage of medicinal plants in such countries is increasing (14).

Acroptilon repens (A. Repens) or Talkhak is a medicinal plant from the Asteraceae family (15). It is a herbaceous and perennial plant, with dividing branches (16). A. Repens root has brown or black colour and produces such buds that grow to 12 meters laterally. This allows the plant to survive for long-term (15). A. Repens found natively in European and Asian countries, including Mongolia, Western Turkestan, Turkey, minor Asia, middle Asia, Iran, Iraq and Afghanistan (17-20).

The Asteraceae family is famous for its sesquiterpenes constituents and potent anti-tumour and anti-inflammatory properties (21). A. Repens also has many beneficial constituents, including sisquiterpenes and also $\alpha$-copaene, $\beta-$ caryophyllene, germacrene D, $\beta$-cubebene, caryophyllene oxide and other essential oils (20, 22). In addition, A. Repens extract as a source of natural antioxidants possessed antimicrobial, anticholinesterase and anti-amylase properties (22).

However, there is not much more evidence of the biological activities of A. Repens $(22,23)$. Thus, this study initiates to evaluate the effect of its root extract on the blood glucose level of diabetic rats, using a streptozotocin-induced model of experimental diabetes. 


\section{Materials and Methods}

\section{Animals}

Thirty adult Sprague-Dawley male rats with body weight of 180 to $200 \mathrm{~g}$, were selected from Khatam Al-Nabieen University Research and Technology Center (KNURTC) randomly. Rats were housed in Plexy-glass cages with free access to food and water. Animals were kept under stable room temperature $\left(23 \pm 2^{\circ} \mathrm{C}\right)$ and a 12 hours light/dark cycle (the light period started at 7 a.m.). The experimental protocol related to animal's use has complied with all the relevant national regulations and institutional policies, so approved by the ethic research board of Khatam Al-Nabieen University and were conducted following the ethical guidelines set by the $8^{\text {th }}$ edition of the National Institute of Health (NIH) guide for the care and use of laboratory animals. Rats were carefully handled to minimize unwanted stress during housing and experiments.

\section{Preparation of extract}

Fresh A. Repens roots were collected from Khwaja-Omari, Ghazni province of Afghanistan and identified by Prof. Nasim Sediqi, Department of Pharmacognosy, Faculty of Pharmacy, Kabul University. Plants were dried in the shade and then grinded. $15 \mathrm{~g}$ of its powder was added into $75 \mathrm{ml}$ distilled water and kept in a dark place for 24 hours. Then, the mixture has filtered three times and evaporated at room temperature (24). As a result, the aqueous extract of $A$. Repens roots was obtained.

\section{Induction of experimental diabetes}

By a single intraperitoneal (i.p.) administration of STZ at a dose of $55 \mathrm{mg} / \mathrm{kg}$ after 8 hours fasting, experimental diabetes has induced. The STZ was dissolved in $0.1 \mathrm{M}$ citrate buffer. Diabetes was confirmed after 72 hours by determining the fasting blood glucose level (FBG). Only rats with $200 \mathrm{mg} / \mathrm{dl} \mathrm{FBG}$ level were chosen for the experiment (4).

\section{Experimental groups.}

Rats were divided into 5 groups $(n=6)$ :

- Group I (Normal), Rats of this group received Normal saline ( $1 \mathrm{ml}$, i.p.) for 15 days;

- Group II (Diabetic), Rats of this group became diabetic and received Normal saline (1 ml, i.p.) for 15 days;

- Group III-V (A. Repens 200, 300, 400 mg/kg), Diabetic rats received $A$. Repens aqueous extract (200, 300 and $400 \mathrm{mg} / \mathrm{kg}$, respectively, i.p.) for 15 days.

\section{Procedures}

Diabetic rats in extract groups received aqueous extract of $A$. Repens by i.p. administration for 15 days. The FBG levels of all rats were measured after 8 hours fasting, by blood withdrawn from the tail of rats using strips and glucometer on the baseline, 0, 5, 10 and 15 days (considering after 3 days of STZ administration). In addition, the intraperitoneal glucose tolerance test (IPGTT) of rats was performed on days 0 and 15 . On 30, 60 and 120 min after i.p. administration of $2 \mathrm{~g}$ glucose load, the blood glucose level was measured (25). The body weight of all rats also measured on baseline, $0,5,10$ and 15 days.

\section{Statistical analysis}

The statistical analysis was done with Graph pad prism (6.07) software. The FBG levels were analyzed by Two-way ANOVA, followed by Dunnett's test multiple comparisons. The difference between the body weight of different groups was analyzed by the non-parametric Kruskal Wallis test. The difference amongst means was considered statistically significant if the $\mathrm{P}<0.05$. The results are expressed as mean $\pm \mathrm{SEM}$.

\section{Results}

\section{Effect of $\boldsymbol{A}$. Repens extract on FBG}

The FBG of all groups was measured on baseline, $0,5,10$ and $15^{\text {th }}$ days. There was not a significant difference in the baseline FBG level between the experimental groups and the diabetic group. However, the FBG level was significantly increased in diabetic groups on days $0,5,10$ and 15 $(\mathrm{P}<0.0001)$. On different days of the experiment, the FBG was considerably decreased in A. Repens 200 and $300 \mathrm{mg} / \mathrm{kg}$ groups, but not in the $400 \mathrm{mg} / \mathrm{kg}$ group, as compared with the diabetic group $(\mathrm{P}<0.0001)$ (see Table 1).

\section{Effect of A. Repens extract on IPGTT}

The blood glucose level of all groups was measured on $0,30,60$ and 120 minutes after a glucose load on days 0 and 15 . On day 0 , there was a significant increase in the blood glucose level of the diabetic group and A. Repens 200, 300 and $400 \mathrm{mg} /$ $\mathrm{kg}$ groups on minutes $0,30,60$ and 120 . On day 15, there was a considerable increase in blood glucose level of the diabetic group and the control group on minutes $0,30,60$ and 120 . The blood glucose level of A. Repens 200 and $300 \mathrm{mg} / \mathrm{kg}$, but not in the $400 \mathrm{mg} /$ $\mathrm{kg}$ group, was significantly decreased on minutes 30 , 60 and 120 after glucose load, as compared with the diabetic group $(\mathrm{P}<0.05)$ (see Table 2$)$.

\section{Effect of $\boldsymbol{A}$. Repens extract on body weight}

The body weight of all groups was measured on baseline, $0,5,10$ and $15^{\text {th }}$ days of the experiment. There was not a significant difference in baseline body weight of all groups $(\mathrm{P}>0.05)$. However, after 15 days, the body weight of the diabetic group was significantly decreased in comparison with the normal group $(\mathrm{P}<0.0001)$. There was not a significant difference in body weight of the diabetic group and each A. Repens 200, 300 and $400 \mathrm{mg} / \mathrm{kg}$ groups $(\mathrm{P}>0.05)$ (see Table 3). 
Table 1. Effect of $A$. Repens aqueous extract on FBG level

Blood glucose level (mg/dl)

\begin{tabular}{|c|c|c|c|c|c|c|}
\hline Groups & Baseline & Day 0 & Day 5 & Day 10 & Day 15 \\
\hline Normal & $75.50 \pm 3.23$ & $69.83 \pm 2.45^{* * * *}$ & $69.83 \pm 2.52^{* * * *}$ & $78.00 \pm 2.39^{* * * *}$ & $73.00 \pm 2.19^{* * * *}$ \\
\hline Diabetic & $76.00 \pm 4.16$ & $284.33 \pm 17.57$ & $301.17 \pm 25.22$ & $301.33 \pm 29.14$ & $321.17 \pm 15.51$ \\
\hline A. Repens $\mathbf{2 0 0} \mathbf{~ m g / k g}$ & $82.33 \pm 5.39$ & $266.00 \pm 17.33$ & $215.50 \pm 22.45^{*}$ & $157.67 \pm 33.97^{* * * *}$ & $119.83 \pm 32.33^{* * * *}$ \\
\hline A. Repens 300 $\mathbf{~ m g / k g}$ & $84.83 \pm 3.10$ & $330.50 \pm 16.01$ & $187.83 \pm 46.82^{* *}$ & $257.67 \pm 38.62$ & $95.67 \pm 13.20^{* * * *}$ \\
\hline A. Repens 400 $\mathbf{~ m g / k g}$ & $88.00 \pm 3.73$ & $346.17 \pm 23.34$ & $277.00 \pm 25.56$ & $301.67 \pm 50.24$ & $377.67 \pm 34.22$ \\
\hline
\end{tabular}

Data are shown as Mean \pm SEM. ${ }^{*}: \mathrm{P}<0.05,{ }^{* *}: \mathrm{P}<0.01,{ }^{* * *}: \mathrm{P}<0.001,{ }^{* * * *}: \mathrm{P}<0.0001$ as compared with the diabetic group.

Table 2. Effect of $A$. Repens aqueous extract on IPGTT

\begin{tabular}{|c|c|c|c|c|c|}
\hline \multirow{2}{*}{ Groups } & & \multicolumn{4}{|c|}{ Blood glucose level (mg/dl) } \\
\hline & & Min 0 & Min 30 & Min 60 & Min 120 \\
\hline \multirow{2}{*}{ Normal } & Day 0 & $69.83 \pm 2.45^{* * * *}$ & $130.67 \pm 5.03^{* * * *}$ & $88.67 \pm 3.01^{* * * *}$ & $71.50 \pm 3.64^{* * * *}$ \\
\hline & Day 15 & $73.00 \pm 2.19^{* * * *}$ & $136.00 \pm 6.57^{* * * *}$ & $91.33 \pm 2.27^{* * * *}$ & $73.00 \pm 4.82^{* * * *}$ \\
\hline \multirow{2}{*}{ Diabetic } & Day 0 & $284.33 \pm 17.57$ & $477.83 \pm 11.26$ & $403.67 \pm 24.17$ & $361.33 \pm 17.51$ \\
\hline & Day 15 & $321.17 \pm 15.51$ & $444.83 \pm 35.85$ & $404.33 \pm 12.63$ & $310.83 \pm 32.50$ \\
\hline \multirow{2}{*}{ A. Repens $200 \mathrm{mg} / \mathrm{kg}$} & Day 0 & $266.00 \pm 17.33$ & $436.00 \pm 21.90$ & $438.17 \pm 36.96$ & $360.83 \pm 43.23$ \\
\hline & Day 15 & $120.17 \pm 32.28^{* * * *}$ & $329.17 \pm 38.23^{* *}$ & $284.67 \pm 26.90^{* *}$ & $184.33 \pm 14.27^{* *}$ \\
\hline \multirow{2}{*}{ A. Repens $300 \mathrm{mg} / \mathrm{kg}$} & Day 0 & $330.50 \pm 16.01$ & $523.83 \pm 75.36$ & $409.83 \pm 28.90$ & $346.17 \pm 20.74$ \\
\hline & Day 15 & $95.67 \pm 13.20^{* * * *}$ & $343.67 \pm 27.97^{*}$ & $284.67 \pm 22.59^{* *}$ & $186.67 \pm 35.17^{* *}$ \\
\hline \multirow{2}{*}{ A. Repens $400 \mathrm{mg} / \mathrm{kg}$} & Day 0 & $346.17 \pm 23.34$ & $438.83 \pm 24.76$ & $395.00 \pm 42.69$ & $350.33 \pm 25.68$ \\
\hline & Day 15 & $377.67 \pm 34.22$ & $452.67 \pm 29.96$ & $415.33 \pm 25.31$ & $357.67 \pm 22.41$ \\
\hline
\end{tabular}

Data are shown as Mean \pm SEM. ${ }^{*}: \mathrm{P}<0.05,{ }^{* *}: \mathrm{P}<0.01,{ }^{* * * *}: \mathrm{P}<0.0001$ as compared with the diabetic group.

Table 3. Effect of $A$. Repens aqueous extract on body weight

\begin{tabular}{|c|c|c|c|c|c|c|}
\hline & \multicolumn{5}{|c|}{ Body Weight (g) } & $\begin{array}{l}\text { Weight gain/ } \\
\text { lost }\end{array}$ \\
\hline Groups & Baseline & Day 0 & Day 5 & Day 10 & Day 15 & Day 0-15 \\
\hline Normal & $183.17 \pm 0.70$ & $184.83 \pm 2.14$ & $192.83 \pm 2.06$ & $199.33 \pm 2.39$ & $207.00 \pm 3.37$ & $23.67 \pm 3.63^{* * * *}$ \\
\hline Diabetic & $193.17 \pm 2.08$ & $169.17 \pm 3.64$ & $169.83 \pm 2.75$ & $164.83 \pm 2.50$ & $160.00 \pm 3.30$ & $-33.17 \pm 3.38$ \\
\hline A. Repens $200 \mathrm{mg} / \mathrm{kg}$ & $195.17 \pm 1.08$ & $170.00 \pm 2.84$ & $172.33 \pm 5.85$ & $172.00 \pm 5.68$ & $172.17 \pm 5.27$ & $-23.00 \pm 5.37$ \\
\hline A. Repens $300 \mathrm{mg} / \mathrm{kg}$ & $182.50 \pm 0.81$ & $167.17 \pm 3.12$ & $160.17 \pm 5.17$ & $160.17 \pm 7.25$ & $158.33 \pm 10.55$ & $-24.17 \pm 10.85$ \\
\hline A. Repens $400 \mathrm{mg} / \mathrm{kg}$ & $183.67 \pm 1.61$ & $161.83 \pm 2.57$ & $162.33 \pm 2.91$ & $158.67 \pm 3.44$ & $158.17 \pm 4.99$ & $-25.50 \pm 4.97$ \\
\hline
\end{tabular}

Data are shown as Mean \pm SEM. ${ }^{* * *}: \mathrm{P}<0.0001$ as compared with the diabetic group.

\section{Discussion}

In this study, the effect of Afghan A. Repens aqueous extract on FBG, IPGTT and body weight of STZ-induced diabetic rats was evaluated. STZ is a diabetogenic and toxic compound that inhibits insulin secretion, thereby producing insulin-dependent diabetes (26). Administration of this compound leads to necrosis in pancreatic beta cells $(26,27)$. Following STZ administration in animals, hyperglycemia, body weight loss and impaired glucose tolerance have been seen $(28$, 29).

Similarly, the present study showed that the administration of STZ in diabetic groups causes a significant increase in blood glucose level, in comparison with the normal group. The blood glucose level of the diabetic group remained high throughout the study. Also, after administration of a glucose load in diabetic rats, their blood glucose level increased significantly, which shows an impaired glucose tolerance in rats. In addition, diabetic groups showed a considerable body weight loss after administration of STZ. As a result, these results showed that an experimental model of diabetes has developed in animals of this study.

Furthermore, i.p. administration of A. Repens root aqueous extract (200 and $300 \mathrm{mg} / \mathrm{kg}$ ) for 15 days could reduce the FBG and improve the glucose tolerance after administration of a glucose load. The reduction of FBG by $A$. Repens extract occurred in a time- and dose-dependent manner, so its effect was greater in low dose $(200 \mathrm{mg} / \mathrm{kg})$ and in long-term administration period (15 days). However, the high dose of A. Repens extract could not decrease the blood glucose level of diabetic rats and did not show any antihyperglycemic property. Moreover, neither of $A$. Repens aqueous extract doses could increase the body weight in diabetic rats, so they could not compensate for the body weight loss resulting from STZ administration.

In addition, studies showed that there is a glucose intolerance in almost all diabetic patients (30). Also, the glucose tolerance test indicates insulin secretion and its function, so GTT is used to evaluate insulin secretion and sensitivity (6). The results of this 
study showed that $A$. Repens extract could decrease the blood glucose level after administration of a glucose load. Thus, A. Repens extract could improve glucose tolerance in diabetic rats. This was also significant in low doses of $A$. Repens extract ( 200 and $300 \mathrm{mg} / \mathrm{kg}$ ). Therefore, one can conclude that low doses of $A$. Repens can enhance insulin secretion in diabetic rats. It is probable that one of the main mechanisms whereby A. Repens could decrease the blood glucose level of diabetic rats is enhancing insulin secretion.

As there is not a previous study on the effect of A. Repens root extract on the blood glucose level of diabetic rats, we cannot compare the data of the present study with previous studies. However, a previous study reports that $A$. Repens extract due to its high phenolic compounds showed an inhibitory effect on the alphaamylase enzyme, which is involved in the management of diabetes. This indicates its potential effect on diabetes treatment (22). In addition, as studies showed that sesquiterpenes are the main constituents of the Asteraceae family, and also some important essential oils have extracted from $A$. Repens $(21,22)$, the positive effects of $A$. Repens extract may be related to these constituents.

Sesquiterpene lactones are one of the largest group of secondary plant metabolites which are the main constituents of the Asteraceae family plants (21). It is showed that the major constituents of A. Repens is also sesquiterpenes (22). Sesquiterpenes have a wide variety of biological activities. Among whose properties, the anti-inflammatory and anti-tumour are significant (21). Inflammation is one of the most important factors involved in the development of diabetes, through a complex process including multiple signalling pathways and kinases (31), it leads to a decrease in insulin secretion, decrease in beta cells mass and increase in insulin resistance (32). Inflammatory cytokines can activate the NF- $\mathrm{KB}$ pathway. This pathway leads to phosphorylation of insulin receptors substrates and thereby produce insulin resistance. It also can impair the pancreatic beta cells function $(31,32)$. On the other hand, studies have shown that plants rich in sesquiterpenes can inhibit the enzymes and mediators involved in the inflammation process (21). Sesquiterpenes decrease the phospholipase A2 and prevent the activation of the NF- $\mathrm{kB}$ pathway, which are responsible for their anti-inflammatory action (33). As a result, the Asteraceae plants family, including A. Repens can probably show positive effects on diabetic rats due to inhibition of the inflammation process.

\section{Conclusion}

All in all, one can conclude that administration of $A$. Repens root aqueous extract in low doses can decrease the fasting blood glucose and improve the glucose tolerance in diabetic rats. It seems that the antidiabetic activity of $A$. Repens is mainly insulin-dependent. We suggest more studies on the effect of $A$. Repens on diabetes, as well as the determination of its main constituents.

\section{Acknowledgements}

This work is supported by the research and technology center of Khatam Al-Nabieen University Kabul, Afghanistan. We thank all officials for their valuable support for providing the equipment and facilities for this study.

\section{References}

1. Chauhan A, Sharma PK, Srivastava P, Kumar N, Dudhe R, Plants having potential antidiabetic activity: a review. Der. Pharm. Lett. 2010; 2(3):369-387.

2. Tiwari BK, Pandey KB, Abidi AB, Rizvi SI, Markers of oxidative stress during diabetes mellitus. J Biomark. 2013; 2013. https://doi.org/ 10.1155/2013/378790.

3. Forbes MJ, Cooper E, Mechanisms of diabetic complications. Physiol. Rev. 2013; 93: 137-188. https://doi.org/10.1152/physrev.00045.2011.

4. Haidari M, Alami K, Hossaini A, Mousavi SY, Effect of Afghan Hibiscus sabdariffa L. and Carum Carvi L. Hydro-alcoholic Extracts Either Alone or in Combination on Blood Glucose Level in Diabetic Rats. Int. J. Ayurved Med. 2020; 11(4): 759-764. https://doi.org/10.47552/ijam.v11i4.1691.

5. Hussaini ZS, Askndari H, Alami K, Mousavi SY, Effect of Rheum Ribes and Urtica Dioica on type 2 diabetic rats. Int. J. Pharm. Phytopharmacol. Res. (eIJPPR). 2021 ;11(1): 63-69.

6. Sadat H, Alami K, Mousavi SY, Effect of Afghan Senjed (Elaeagnus angustifolia L.) leaves aqueous alcoholic extract on blood glucose level of diabetic rats. Pharmacog. J. 2020; 12(6): 1218-1222. https:// doi.org/10.5530/pj.2020.12.170.

7. Rao MU, Sreenivasulu M, Chengaiah B, Reddy KJ, Chetty CM, Herbal medicines for diabetes mellitus: a review. Int. J. PharmTech. Res. 2010; 2(3): 1883-1892.

8. Kane MP, Abu-Baker A, Busch RS, The utility of oral diabetes medications in type 2 diabetes of the young. Curr. Diabetes. Rev. 2005; 1(1): 83-92. https://doi.org/10.2174/1573399052952569.

9. Alami K, Mousavi SY, Afghan Chehelghoza (Pinus gerardiana L.) Pine Nut Diet Enhances the Learning and Memory in Male Rats. Diet. Suppl. 2020; 12: 277-288. http://doi.org/10.2147/NDS.S278350.

10. Alami K, Mousavi SY, Effect of Afghan chehelghoza (Pinus gerardiana L.) on Food Consumption, Body, and Brain Weight of Male Rats. J. Complement. Med. Res. 2021; 12(1): 5-8. https://doi.org/10.5455/jcmr.2021.12.01.02.

11. Alami K, Haidari M, Ebrahimi K, Bakhtiari AA, Sajjadi M, Mousavi SY, Effect of Afghan Senjed (Elaeagnus Angustifolia L.) Leaves Aqueous Extract on Memory of Male Rats. Int. J. Ayurvedic. Med. 2021; 12(1): 62-67. https://doi.org/10.47552/ ijam.v12i1.1765.

12. Akbari E, Alami K, Hossaini D, Nazari ML, Salehi MH, Sajjadi M, Mousavi SY, Effect of Afghan Saffron (Crocus sativus L.) aqueous extract on withdrawal signs in morphine-dependent rats. 
Pharmacog. J. 2020; 12(6s): 1727-1731. https:// doi.org/10.5530/pj.2020.12.234.

13. Hossaini D, Alami K, Nazari ML, Ebrahimi K, Salehi MH, Mousavi SY, Effect of Afghan Ferula assa-foetida L. oleo Gum Resin Aqueous Extract on Withdrawal Signs in Morphine-Dependent Rats. J. Complement. Med. Res. 2021; 12(1): 70-74. http:// dx.doi.org/10.5455/jcmr.2021.12.01.07.

14. Mirhoseini M, Baradaran A, Rafieian-Kopaei M, Medicinal plants, diabetes mellitus and urgent needs. J. HerbMed. Pharmacol. 2013; 2(2): 53-54.

15. Mengüç Ç, Çoksarı G, Seasonal Changes in Soluble Carbohydrates of Russian Knapweed's Rhizomes. J. Res. Weed. Sci. 2019; 2(3. pp. 180-281):190-202. https://doi.org/10.26655/ JRWEEDSCI.2019.2.3.2.

16. Nadaf M, Nasrabadi M, Halimi M, Yazdani Z, Javanshir A, Ramazani S, Mohaddesi B, Identification of non-polar chemical compounds Acroptilon repens growing in Iran by GC-MS. Middle-East. J. Sci. Res. 2013; 17(5): 590-592. ht t p s : / / d o i . o r g/ 10 . 5829 / idosi.mejsr.2013.17.05.75149.

17. Quintana N, Weir TL, Du J, Broeckling CD, Rieder JP, Stermitz FR, Paschke MW, Vivanco JM, Phytotoxic polyacetylenes from roots of Russian knapweed (Acroptilon repens (L.) DC.). Phytochem. 2008; 69(14): 2572-2578. https:// doi.org/10.1016/j.phytochem.2008.07.015.

18. Laufenberg SM, Sheley RL, Jacobs JS, Borkowski $\mathrm{J}$, Herbicide effects on density and biomass of Russian knapweed (Acroptilon repens) and associated plant species. Weed. Technol. 2005; 19(1): 62-72. https://doi.org/10.1614/WT-03-233R1

19. Gaskin JF, Littlefield JL, Invasive Russian Knapweed (Acroptilon repens) Creates Large Patches Almost Entirely by Rhizomic Growth. Invasive. Plant. Sci. Manag. 2017; 10(2): 119-124. https://doi.org/10.1017/inp.2017.9.

20. Tunalier Z, Candan NT, Demirci B, Baser KH, The essential oil composition of Acroptilon repens (L.) DC. of Turkish origin. Flavour. Frag J. 2006; 21(3): 462-464. https://doi.org/10.5650/jos.ess 16011

21. Merfort I, Perspectives on sesquiterpene lactones in inflammation and cancer. Curr. Drug. Targets. 2011; 12(11): $1560-1573$. https://doi.org/ $10.2174 / 138945011798109437$.

22. Afsharnezhad M, Shahangian SS, Rasti B, Ghasemi MF, Inhibitory Potential of Acroptilon repens against Key Enzymes involved in Alzheimer and Diabetes, Phytochemical Profile, Radical Scavenging, and Antibacterial Activity. Iran. Biomed. J. 2021; 25(1): 21-32. https://doi.org/ 10.29252/ibj.25.1.21.

23. Mosaddegh M, Irani M, Hamzeloo-Moghadam M, Acroptilon repens induces apoptosis in human breast adenocarcinoma. Bangladesh. J. Pharmacol. 2018; 13(4): 362-366. https://doi.org/10.3329/ bjp.v13i4.38026.

24. Thusoo S, Gupta S, Sudan R, Kour J, Bhagat S, Hussain R, Bhagat $M$, Antioxidant activity of essential oil and extracts of Valeriana jatamansi roots. BioMed. Res. Int. 2014; 2014. https://doi.org/ 10.1155/2014/614187.

25. Jalal R, Bagheri SM, Moghimi A, Rasuli MB, Hypoglycemic effect of aqueous shallot and garlic extracts in rats with fructose-induced insulin resistance. J. Clin. Biochem. Nutr. 2007; 41(3): 218-223. https://doi.org/10.3164/jcbn.2007031.

26. Lenzen S, The mechanisms of alloxan-and streptozotocin-induced diabetes. Diabetologia. 2008; 51: 216-226. https://doi.org/10.1007/ s00125-007-0886-7.

27. Szkudelski T, The mechanism of alloxan and streptozotocin action in B cells of the rat pancreas. Physiol. Res. 2001; 50: 537-546.

28. Eleazu CO, Eleazu KC, Chukwuma S, Essien UN, Review of the mechanism of cell death resulting from streptozotocin challenge in experimental animals, its practical use and potential risk to humans. J. Diabetes. Metab. Disord. 2013; 12: 60. https://doi.org/10.1186/2251-6581-12-60.

29. Deeds MC, Anderson JM, Armstrong AS, Gastineau DA, Hiddinga HJ, Jahangir A, Eberhardt NL, Kudva YC, Single dose streptozotocin-induced diabetes: considerations for study design in islet transplantation models. Lab. Anim. 2011; 45: 131-140. https://doi.org/10.1258/la.2010.010090.

30. Ayala JE, Samuel VT, Morton GJ, Obici S, Croniger CM, Shulman GI, Wasserman DH, McGuinness OP, Standard operating procedures for describing and performing metabolic tests of glucose homeostasis in mice. Dis. Model. Mech. 2010; 3(9-10): 525-534. https://doi.org/10.1242/ dmm.006239.

31. Ma X, Chen Z, Wang L, Wang G, Wang Z, Dong $X$, Wen $B$, Zhang $Z$, The pathogenesis of diabetes mellitus by oxidative stress and inflammation: its inhibition by berberine. Front. Pharmacol. 2018; 9: 782. https://doi.org/10.3389/fphar.2018.00782.

32. Agrawal NK, Kant S, Targeting inflammation in diabetes: Newer therapeutic options. World. J. Diabetes. 2014; 5(5): 697. https://doi.org/10.4239/ wjd.v5.i5.697.

33. Kreuger MR, Grootjans S, Biavatti MW, Vandenabeele P, D'Herde K, Sesquiterpene lactones as drugs with multiple targets in cancer treatment: focus on parthenolide. Anti-cancer. Drugs. 2012; 23(9): 883-896. https://doi.org/10.1097/ cad.0b013e328356cad9. 